\title{
Enzymes involved in DNA ligation and end-healing in the radioresistant bacterium Deinococcus radiodurans Melanie Blasius ${ }^{1}$, Rebecca Buob ${ }^{1}$, Igor V Shevelev ${ }^{1,2}$ and Ulrich Hubscher*1
}

Address: ${ }^{1}$ Institute of Veterinary Biochemistry and Molecular Biology, University of Zürich-Irchel, Winterthurerstrasse 190, 8057 Zürich, Switzerland and 2 Donnelly Centre for Cellular and Biomolecular Research (CCBR), Department of Biochemistry \& Department of Medical Genetics and Microbiology University of Toronto, 160 College Street, Toronto, Canada

Email: Melanie Blasius - blasius@vetbio.uzh.ch; Rebecca Buob - buob@vetbio.uzh.ch; Igor V Shevelev - igor.chevelev@utoronto.ca; Ulrich Hubscher* - hubscher@vetbio.uzh.ch

* Corresponding author

Published: 16 August 2007

BMC Molecular Biology 2007, 8:69 doi:10.1 186/1471-2199-8-69

Received: 24 April 2007

Accepted: 16 August 2007

This article is available from: http://www.biomedcentral.com/I47I-2199/8/69

(C) 2007 Blasius et al; licensee BioMed Central Ltd.

This is an Open Access article distributed under the terms of the Creative Commons Attribution License (http://creativecommons.org/licenses/by/2.0), which permits unrestricted use, distribution, and reproduction in any medium, provided the original work is properly cited.

\begin{abstract}
Background: Enzymes involved in DNA metabolic events of the highly radioresistant bacterium Deinococcus radiodurans are currently examined to understand the mechanisms that protect and repair the Deinococcus radiodurans genome after extremely high doses of $\gamma$-irradiation. Although several Deinococcus radiodurans DNA repair enzymes have been characterised, no biochemical data is available for DNA ligation and DNA endhealing enzymes of Deinococcus radiodurans so far. DNA ligases are necessary to seal broken DNA backbones during replication, repair and recombination. In addition, ionizing radiation frequently leaves DNA strand-breaks that are not feasible for ligation and thus require end-healing by a 5'-polynucleotide kinase or a 3'-phosphatase. We expect that DNA ligases and end-processing enzymes play an important role in Deinococcus radiodurans DNA strand-break repair.

Results: In this report, we describe the cloning and expression of a Deinococcus radiodurans DNA ligase in Escherichia coli. This enzyme efficiently catalyses DNA ligation in the presence of $\mathrm{Mn}(\mathrm{II})$ and $\mathrm{NAD}^{+}$as cofactors and lysine 128 was found to be essential for its activity. We have also analysed a predicted second DNA ligase from Deinococcus radiodurans that is part of a putative DNA repair operon and shows sequence similarity to known ATP-dependent DNA ligases. We show that this enzyme possesses an adenylyltransferase activity using ATP, but is not functional as a DNA ligase by itself. Furthermore, we identified a 5'-polynucleotide kinase similar to human polynucleotide kinase that probably prepares DNA termini for subsequent ligation.

Conclusion: Deinococcus radiodurans contains a standard bacterial DNA ligase that uses $N A D^{+}$as a cofactor. Its enzymatic properties are similar to $E$. coli DNA ligase except for its preference for $\mathrm{Mn}(\mathrm{II})$ as a metal cofactor. The function of a putative second DNA ligase remains unclear, but its adenylyltransferase activity classifies it as a member of the nucleotidyltransferase family. Characterization of another protein from the same operon revealed a 5'-polynucleotide kinase with a possible role in DNA strand-break repair.
\end{abstract}




\section{Background Deinococcus radiodurans}

Deinococcus radiodurans (D. radiodurans) exhibits an extraordinary resistance to ionizing radiation. Ionizing radiation generates a variety of DNA damages, including many types of base damages as well as single-strand and double-strand breaks, the latter being the most lethal damage for a living cell. D. radiodurans can survive irradiation up to 5,000 Gy without measurable loss of viability, and it seems likely that this resistance is based on mechanisms that ensure limited DNA and protein degradation and provide an efficient and accurate DNA strand-break repair [1]. High intracellular levels of $\mathrm{Mn}$ (II) protect proteins and allow fast repair of damaged DNA after irradiation [2,3]. Prokaryotes can repair double-strand breaks by homologous recombination, but proteins implicated in non-homologous end-joining have also been identified recently, such as Ku homologs and additional DNA ligases $[4,5]$. However, no Ku homolog has been discovered in the genome of $D$. radiodurans. Zahradka et al. found that a mechanism called extended synthesis-dependent strandannealing accounts for most of the strand-break repair [6], although additional DNA repair pathways might contribute to the efficient DNA repair. In any case, a DNA ligase is essential for DNA repair and a 5'-polynucleotide kinase/ 3'-phosphatase would ensure that DNA strand-breaks could be invariably ligated.

\section{DNA ligases}

DNA ligases play essential roles in replication, recombination and repair since they join broken DNA strands by catalysing the formation of a phosphodiester bond between the 3' hydroxyl end of one strand and the 5' phosphate end of another. Ligation occurs via three nucleotidyltransfer steps: (i) a covalent enzyme-adenylate intermediate is formed, (ii) the adenylate group (AMP) is transferred to the 5'-phosphate terminus of the DNA molecule and (iii) the gap in the DNA molecule is sealed when the DNA ligase catalyses displacement of the AMP residue through the attack by the adjacent 3' hydroxyl group of the DNA [7]. For all DNA ligases, the AMP is linked to a highly conserved lysine residue in the catalytic motif of the enzyme. DNA ligases can use either ATP or $\mathrm{NAD}^{+}$as an AMPdonor. $\mathrm{NAD}^{+}$-dependent DNA ligases are found exclusively in bacteria, certain archaea, and viruses whereas ATP-dependent DNA ligases can be found in eukaryotes, archaea and several viruses including bacteriophages. Recently, it was shown that some bacterial genomes also encode an additional ATP-dependent DNA ligase, some of which were further characterised [7].

The D. radiodurans genome contains the gene DR2069 encoding an $\mathrm{NAD}^{+}$-dependent DNA ligase, here designated as LigA. The gene DRB0100 encodes another possible diverged homolog of ATP-dependent ligases. As the function of this protein remains unclear it will be called DRB0100 throughout this paper. This predicted ATPdependent DNA ligase contains all catalytic residues, and its expression is strongly upregulated upon $\gamma$-irradiation [8]. In addition, DRB0100 belongs to a putative DNA repair operon together with the genes DRB0098 and DRB0099. DRB0098 has been predicted to encode a kinase/phosphatase with an unusual domain architecture [9] whereas DRB0099 is classified as a domain of unknown function with weak similarity to the macro domain family [10].

\section{Polynucleotide kinases and 3' phosphatases}

Not all DNA strand breaks possess ligatable ends, i.e. a 5' phosphate and a 3' OH terminus. The 5' phosphate can be missing and $\gamma$-irradiation and reactive oxygen can lead to the formation of 3' phosphate or phosphoglycolate ends $[11,12]$. Enzymatic activity is required to remove the $3^{\prime}$ phosphate moiety and to phosphorylate the 5' end at the DNA nick to allow for DNA ligation. Both reactions are catalysed by bifunctional PNKPs. The best characterised PNKP is T4 PNK that is involved in the repair of host tRNA [13]. Additional PNKPs were identified in other viruses and all these viral enzymes can use either DNA or RNA as a substrate. PNKPs were also found in some eukaryotes, e.g. human, Caenorhabditis elegans and Schizosaccharomyces pombe, where they seem to play an important role in the repair of single-strand and double-strand breaks [14-16]. However, the eukaryotic enzymes can only use DNA as a substrate. Pnk1 from Schizosaccharomyces pombe possesses both 3'-phosphatase and 5'-polynucleotide kinase activities, whereas TPP1 from Saccharomyces cerevisiae shows only 3'-phosphatase activity. In other organisms, the kinase and phosphatase activities seem to be uncoupled as well, e.g. in Arabidopsis thaliana. Only one bacterial PNKP from Clostridium thermocellum has been characterised so far [17], showing similarity to viral PNKPs. D. radiodurans also seems to possess a PNKP encoded by the gene DRB0098, although the PNKP possesses a special domain architecture [9]. The order of the phosphatase and kinase domains is the similar to eukaryotic PNKPs; in contrast, viral PNKPs have a reversed order of the two domains. The predicted phosphatase domain of the $D$. radiodurans PNKP belongs to the HD hydrolase superfamily [18], and, so far, only one viral PNKP containing this domain has been shown to possess 3'-phosphatase activity [19]. The $D$. radiodurans PNKP is part of the putative DNA repair operon together with the predicted ATP-dependent DNA ligase DRB0100 and the expression of this operon is strongly upregulated upon irradiation. Thus, a role for the encoded proteins in DNA repair has been suggested [8].

In this work we analyse two putative DNA ligases and one predicted 5'-polynucleotide kinase/3'-phosphatase from Deinococcus radiodurans. 


\section{Results \\ Prediction of two DNA ligases for D. radiodurans}

Sequence comparison of the two predicted $D$. radiodurans DNA ligases with other bacterial DNA ligases showed that LigA displays a strong similarity to other $\mathrm{NAD}^{+}$-dependent DNA ligases (Figure 1A) and comprises the expected adenylation, OB fold and BRCT domains. Like other NAD+dependent DNA ligases LigA also contains a zinc finger and a helix-hairpin-helix motif presumably involved in DNA binding (Figure 1B). By contrast, the predicted ATPdependent DNA ligase DRB0100 shows poor sequence similarity to other bacterial ATP-dependent ligases, but contains all catalytic residues (Figure $1 \mathrm{~A}$ and [8]). The DRB0100 protein consists of the adenylation domain only and lacks all other domains present in LigA (Figure 1B); especially no DNA binding motif could be detected.

\section{Purification of two recombinant DNA ligases from D. radiodurans}

Both genes encoding putative DNA ligases, DRB0100 and DR2069, were amplified from genomic D. radiodurans DNA using specific primers (see Table 1) and cloned into a pRSETb vector for recombinant protein expression in $E$. coli cells with a hexahistidine tag at the $\mathrm{N}$ terminus. For both proteins, adenylation mutants were created by replacing the conserved lysine residue with an alanine, resulting in a DRB0100 K40A mutant and a LigA K128A mutant, respectively. All wild-type and mutant proteins were expressed in E. coli BL21(DE3) cells and purified to near homogeneity over a HisTrap ${ }^{\mathrm{rm}} \mathrm{HP}$ column and two additional ion exchange columns (Figure 1C).

\section{A DNA ligase from D. radiodurans performs efficient strand joining in the presence of $\mathrm{NAD}^{+}$and $\mathrm{Mn}(\mathrm{II})$ and possesses adenylyltransferase activity}

We tested the ability of the LigA wt and the K128A mutant to ligate a duplex DNA substrate containing a single nick. Ligase activity was measured as conversion of a $5^{1}-\left[{ }^{32} \mathrm{P}\right]-$ labelled deoxyribose oligomer of 19 nucleotides into an internally labelled oligomer of 44 nucleotides. LigA showed maximum ligation activity with $1 \mathrm{mM} \mathrm{MnCl}_{2}, 5$ $\mu \mathrm{M} \mathrm{NAD}{ }^{+}$and a $\mathrm{pH}$ of 6.8 at a temperature of $30^{\circ} \mathrm{C}$. Higher concentrations of $\mathrm{MnCl}_{2}$ or $\mathrm{NAD}^{+}$had an inhibitory effect on the enzymatic activity. The enzyme was 10 times less active in the presence of $\mathrm{MgCl}_{2}$, and even inactive when tested with $1 \mathrm{mM}$ ATP (data not shown). To exclude the possibility that the observed activity is caused by a copurified $E$. coli ligase, we created a K128A mutant that lacks the proposed site of adenylation (Figure 1A). The LigA K128A mutant showed almost no ligation activity confirming that the observed ligation activity results from the $D$. radiodurans $\mathrm{NAD}^{+}$-dependent DNA ligase (Figure 2A). The residual DNA ligation does probably not result from a contamination with E. coli DNA ligase, as the activity was strongly decreased in presence of $4 \mathrm{mM}$ $\mathrm{MgCl}_{2}$, which is optimal for $E$. coli DNA ligase (data not shown). In an adenylyltransferase activity assay LigA wt formed an AMP-ligase complex, whereas complex formation was not detected with the K128A mutant (Figure 2A, right). Thus, lysine 128 is essential for the first step of DNA ligation. The kinetic analysis of the wt reaction using different concentrations of nicked DNA displayed typical Michaelis-Menten kinetics with an apparent $K_{\mathrm{M}}$ of $105 \pm$ $16 \mathrm{nM}$ (Table 2).

Table I: PCR primer sequences used in this study

\begin{tabular}{|c|c|c|}
\hline Primer name & Used for & Sequence (5'-3') \\
\hline DRBOIOOF & cloning of DRBOI00wt into pRSETb & $\begin{array}{l}\text { CGCGGATCCGATGCGAGTCAAATACCCTT } \\
\text { C }\end{array}$ \\
\hline DRBOIOOR & cloning of DRBOI00wt into pRSETb & CGCGGATCCGTCATGACTGCTCCTGGCG \\
\hline DRBOI00_mutF & introduction of $\mathrm{K} 40 \mathrm{~A}$ mutation into $\mathrm{DRBO} 100$ & CGTCGTGACCGAGGCGCTCGACGGCG \\
\hline DRBOI00_mutR & introduction of $\mathrm{K} 40 \mathrm{~A}$ mutation into $\mathrm{DRBO} 100$ & CGCCGTCGAGCGCCTCGGTCACGACG \\
\hline DR2069F & cloning of DR2069 wt into pRSETb & CGCGGATCCGATGCGTTACCCTGGGCGC \\
\hline DR2069R & cloning of DR2069 wt into pRSETb & CGCGGATCCGTCAGCTTTCAGCGGGGGC \\
\hline mut_DR2069F & introduction of KI28A mutation into DR2069 & CCGGCGAGCTGGCAATCGACGGCCT \\
\hline mut_DR2069R & introduction of KI28A mutation into DR2069 & CAGGCCGTCGATTGCCAGCTCGCCGG \\
\hline DRB0098F & cloning of DRB0098 into pRSETb & $\begin{array}{l}\text { CGCGGATCCGATGAACCGCAAAAACCGTA } \\
\text { C }\end{array}$ \\
\hline DRB0098R & cloning of DRB0098 into pRSETb & $\begin{array}{l}\text { CGCGGATCCGTCAGGAGGTAGATGAGGG } \\
\text { CAG }\end{array}$ \\
\hline 98_R37ILF & introduction of R37IK mutation into DRB0098 & $\begin{array}{l}\text { GGTCAGCTCGGAGCAAAAATCAGCGGG } \\
\text { AGAGAGC }\end{array}$ \\
\hline 98_R37ILR & introduction of R37IK mutation into DRB0098 & $\begin{array}{l}\text { GCTCTCTCCCGCTGATTTTTGCTCCGA } \\
\text { GCTGACC }\end{array}$ \\
\hline
\end{tabular}

All oligonucleotides were desalted and used in a final concentration of $0.4 \mu \mathrm{M}$. T7 sequencing primers can be found at the Microsynth webpage. Bold bases represent those exchanged in the site-directed mutagenesis. Restriction sites are shown in italics. 


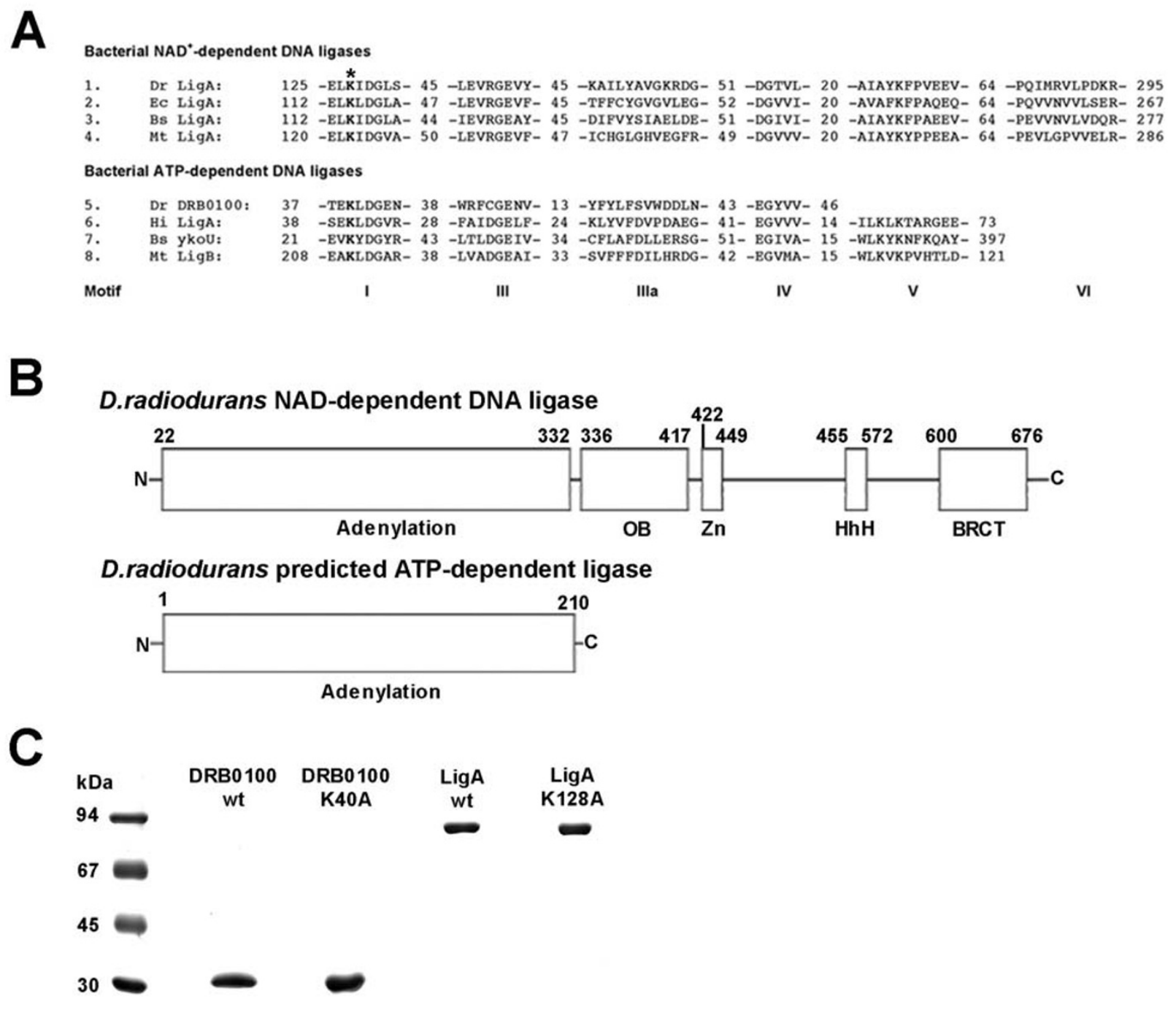

Figure I

Alignment and purification of two predicted D. radiodurans DNA ligases. A. Alignment of eight colinear sequence elements in bacterial DNA ligases based on previous studies of DNA ligase motifs [7, 34] using CLUSTALW alignment [35]. The numbers of amino acids between the motifs are indicated. The alignment of motif VI is not shown for the ATP-dependent DNA ligases since the homology is very poor. Note that the putative ATP-dependent DNA ligase from $D$. radiodurans seems to lack also motif $\mathrm{V}$. The conserved adenylated lysine residue is depicted in bold and labelled with an asterisk. Dr, Deinococcus radiodurans, Ec, Escherichia coli, Bs, Bacillus subtilis, Mt, Mycobacterium tuberculosis, Hi, Haemophilus influenzae. B. Predicted domain structures of $D$. radiodurans $\mathrm{NAD}^{+}$-dependent DNA ligase (LigA) and ATP-dependent DNA ligase (DRB0 I00). The LigA protein scheme is based on homology searches using the NCBI conserved domain database and the SMART conserved domain database. OB, oligonucleotide-binding fold, $\mathrm{Zn}$, zinc finger, $\mathrm{HhH}$, helixhairpin-helix motif I, BRCT, BRCAI C-terminal domain. C. LigA and DRBOI00 and their corresponding adenylation mutants LigA KI28A and DRBOI00 K40A were purified over one metal affinity column and two ion exchange columns to near homogeneity as described in Methods. $3 \mu \mathrm{g}$ of each protein were loaded onto a 10\% SDS-PAGE and the gel was stained with Coomassie Blue R250. 


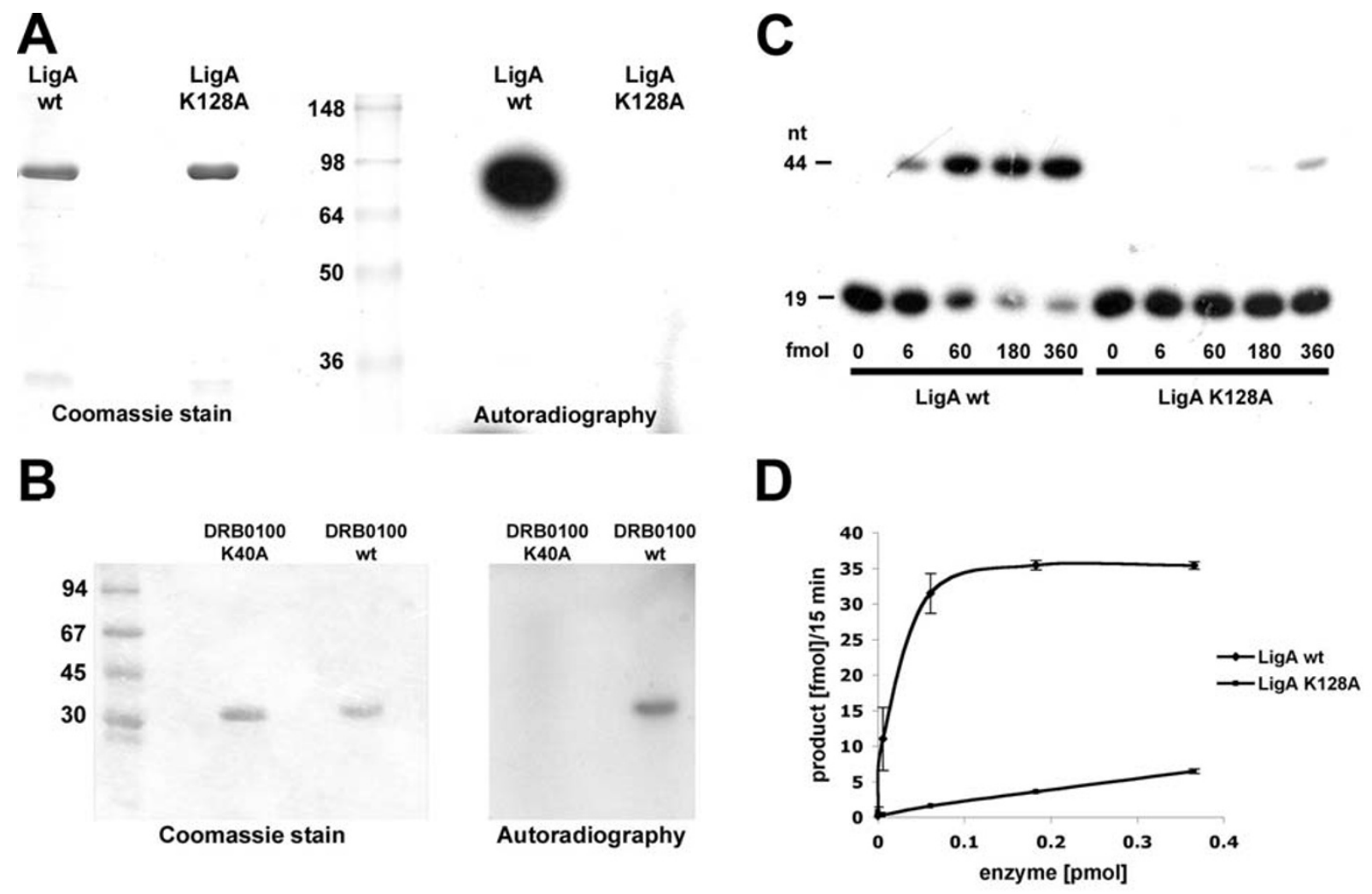

Figure 2

DNA ligation and adenylyltransferase activities of the putative recombinant DNA ligases. A. LigA wt and LigA $\mathrm{KI} 28 \mathrm{~A}$ were incubated with [32P]-NAD ${ }^{+}$and adenylyltransferase activity was detected by SDS-PAGE. Protein bands were visualized with Coomassie Blue R250 (left) and by autoradiography (right). B. DRBOI00 wt and K40A were incubated with $\alpha$-[ ${ }^{32}$ ]ATP. Protein-AMP complexes and free $\alpha$-[32P]-ATP were separated by SDS-PAGE. Proteins were stained with Coomassie Blue R250 (left) and detected by autoradiography (right). C. Titration of LigA wt and LigA KI28A on a nicked DNA substrate. Indicated amounts of LigA wt and LigA K I28A were incubated with the DNA substrate as described in the Methods section. [ $\left.{ }^{32} \mathrm{P}\right]-$ labelled DNA oligonucleotides were visualized by autoradiography. D. Quantification of three independent experiments as shown in C. Error bars are given as the standard error of the mean.

Table 2: $K_{M}$ values of prokaryotic NAD+-dependent DNA ligases

\begin{tabular}{cccc}
\hline Organism & ${\mathbf{T ~}\left[{ }^{\circ} \mathbf{C}\right]}$ & $\boldsymbol{K}_{\mathbf{M}}$ [nM] & Reference \\
\hline D. radiodurans & 30 & $105 \pm 16$ & This work \\
E. coli & 18 & 179 & Georlette et al., 2000 \\
E. coli & 30 & 702 & Georlette et al., 2000 \\
E. coli & 45 & 2040 & Georlette et al., 2000 \\
P. haloplanktis & 4 & 165 & Georlette et al., 2000 \\
P. haloplanktis & 18 & 296 & Georlette et al., 2000 \\
P. haloplanktis & 25 & 631 & Georlette et al., 2000 \\
T. scotoductus & 45 & 236 & Georlette et al., 2000 \\
T. scotoductus & 60 & 465 & Georlette et al., 2000
\end{tabular}

$K_{M}$ values for nicked DNA substrates. Details for $K_{M}$ determination of $D$. radiodurans $N A D^{+}$-dependent DNA ligase are described in Methods. $K_{M}$ is the mean of 3 independent experiments and the error is given as standard error of the mean. 


\section{Divalent cation dependence and specificity of the DNA strand-joining by LigA}

Ligation of a nicked DNA by LigA required a divalent cation cofactor and was best in the presence of $1 \mathrm{mM} \mathrm{MnCl}_{2}$ (Figure $3 \mathrm{~A}$ ). $\mathrm{MnCl}_{2}$ could be replaced by $\mathrm{MgCl}_{2}$ or $\mathrm{CaCl}_{2}$ leading however to a 10-fold decrease of activity (Figure 3A). The optimal concentration of divalent cation was 1 $\mathrm{mM}$ for $\mathrm{MgCl}_{2}$ and $2 \mathrm{mM}$ for $\mathrm{CaCl}_{2}$. Only low levels of DNA ligation were observed with $\mathrm{NiCl}_{2}$ and $\mathrm{ZnCl}_{2}$, the optimal concentrations being 2 and $3 \mathrm{mM}$, respectively (Figure $3 \mathrm{~B}$ ). $\mathrm{CoCl}_{2}$ could not serve as a divalent cation cofactor (Figure $3 \mathrm{~B}$ ).

DRBO I 00, a predicted ATP-dependent DNA ligase from D. radiodurans, forms a complex with $A M P$, but does not ligate DNA or RNA in vitro

DRB0100 has been predicted to be an ATP-dependent DNA ligase consisting only of the adenylation domain. We first tested whether the DRB0100 protein possesses an adenylation activity using ATP as an AMP-donor and whether lysine residue 40 is indeed essential for AMP binding. The adenylyltransferase activity was tested by incubating $1 \mu \mathrm{g}$ of recombinant protein with $\alpha-\left[{ }^{32} \mathrm{P}\right]-\mathrm{ATP}$. A complex was formed between the wild-type protein and [32P]-AMP, which was completely absent for the K40A mutant, confirming that DRB0100 possesses adenylyltransferase activity and therefore belongs to the family of nucleotidyltransferases (Figure 2B). We further tested whether DRB0100 is able to ligate DNA or RNA substrates using $\mathrm{NAD}^{+}$or ATP as a cofactor. However, we did not detect a ligation product with any conditions used [see Additional file 1 and Additional file 2].

\section{Purification of a putative 5'-polynucleotide kinase/3'- phosphatase from D. radiodurans with an unusual domain architecture}

The PNKP encoded by D. radiodurans has a phosphatasekinase domain architecture similar to the eukaryotic PNKPs. In contrast, the viral T4 PNK has a reverse domain order with the kinase domain at the $\mathrm{N}$-terminus and the phosphatase domain at the C-terminus. Comparison of D. radiodurans and human PNKP shows that the bacterial protein is smaller than the human homolog and contains a phosphatase domain belonging to the superfamily of HD phosphohydrolases. The human enzyme contains a distinct phosphatase domain with some similarity to histidinol phosphatase and related phosphatases (Figure $4 \mathrm{~A})$.

The gene DRB0098 encoding a putative PNKP was amplified via PCR from genomic D. radiodurans DNA. The gene was cloned into a pRSETb vector and arginine 371 was mutated to lysine using mutagenic primers for PCR. Arginine 371 was chosen based on sequence comparisons with the well-characterised T4 PNK. We estimated that it
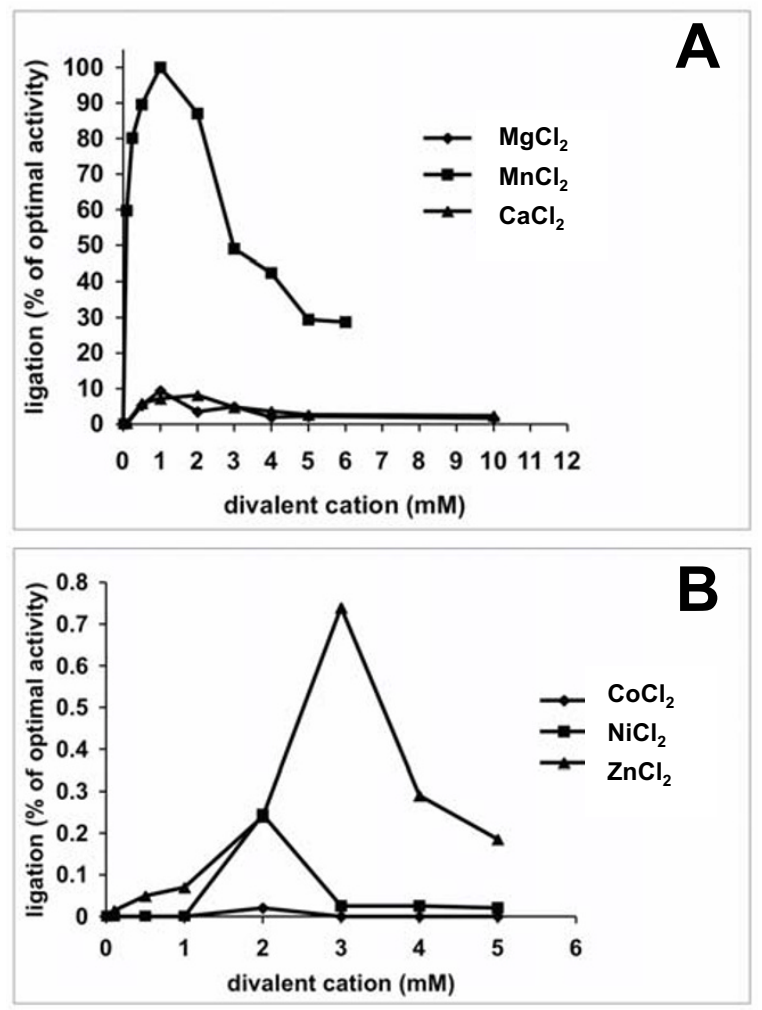

Figure 3

Divalent cation requirements for LigA activity. A.

Titration of $\mathrm{MgCl}_{2}, \mathrm{MnCl}_{2}$ and $\mathrm{CaCl}_{2}$. Ligation assays were performed with $60 \mathrm{fmol}$ of LigA wt and increasing amounts of divalent cations, and quantified as described in Methods. Ligation activity obtained with $\mathrm{I} \mathrm{mM} \mathrm{MnCl}_{2}$ was set as $100 \%$ and relative DNA ligation activity is shown as the average of 2 experiments. $\mathrm{B}$. Titration of $\mathrm{CoCl}_{2}, \mathrm{NiCl}_{2}$ and $\mathrm{ZnCl}_{2}$. Ligation assays were performed as in $\mathrm{A}$. Note that the ordinate has a scale of about 2 orders of magnitude lower than in $A$ for better illustration of the divalent cation optima.

should correspond to arginine 126 in T4 PNK, which is required for polynucleotide kinase activity [20].

Both proteins, DRB0098 wt and DRB0098 R371K were expressed in E. coli BL21(DE3) cells with an N-terminal hexa-histidine tag. The proteins were purified over a HisTrap $\mathrm{HP}^{\mathrm{Tм}}$ column, a HiTrap Heparin $\mathrm{HP}^{\mathrm{TM}}$ column and finally a HiTrap SP $\mathrm{HP}^{\mathrm{TM}}$ column to apparent homogeneity (Figure 4B). 
A PNKP from Deinococcus radiodurans

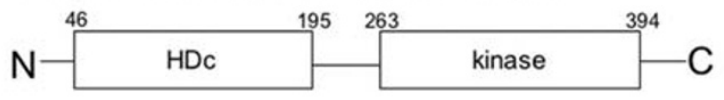

PNKP from Homo sapiens
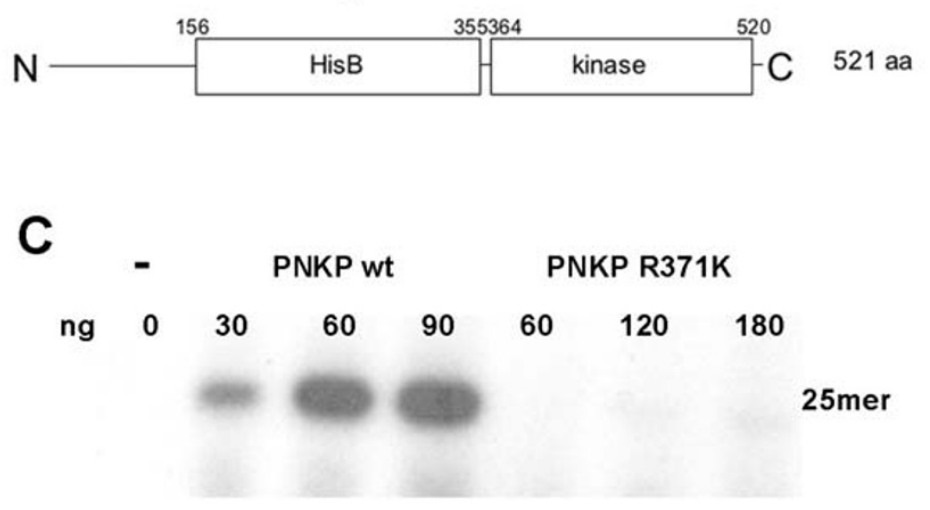

B

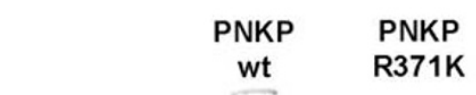

94

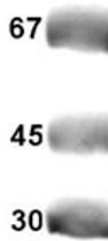

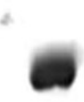

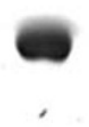

30

\section{Figure 4}

Purification of a putative PNKP from D. radiodurans and analysis of its 5' kinase and 3' phosphatase activities. A. Scheme of PNKP from D. radiodurans and $H$. sapiens. Protein domains are depicted according to predictions based on sequence similarities [36]. Schemes are not drawn to scale. HD, HD domain, kinase, polynucleotide kinase domain, HisB, histidinol phosphatase and related phosphatases domain. B. $3 \mu \mathrm{g}$ of either D. radiodurans PNKP wt or PNKP R37IK mutant were loaded onto a 10\% SDS-PAGE and subsequently stained with Coomassie Blue R250. Both proteins were purified over 3 columns. Details are described in Methods. C. Titration of the D. radiodurans PNKP wt and PNKP R37IK mutant to compare their polynucleotide kinase activity on a $5^{\prime} \mathrm{OH} 25$ mer deoxyribose oligonucleotide. Different amounts of enzyme were incubated with the DNA substrate and $\gamma$-[32P]-ATP as described in Methods. [32P]-labelled 25 mer was detected by autoradiography.

\section{Analysis of the D. radiodurans PNKP polynucleotide kinase/3'-phosphatase activity}

Polynucleotide activity for the $D$. radiodurans PNKP was shown as transfer of ${ }^{32} \mathrm{P}_{\mathrm{i}}$ from $\gamma-\left[{ }^{32} \mathrm{P}\right]$-ATP to the $5^{\prime} \mathrm{OH}$ end of a 25 mer oligodeoxyribonucleotide. The resulting $5^{\prime}\left[{ }^{32} \mathrm{P}\right]$-labelled product was separated from the free $\gamma$ $\left[{ }^{32} \mathrm{P}\right]-\mathrm{ATP}$ by polyacrylamide gel electrophoresis and detected by autoradiography. The wild-type protein showed clear 5'-polynucleotide kinase activity with an optimal $\mathrm{MnCl}_{2}$ concentration of only $0.25 \mathrm{mM}$. Mutation of arginine 371 to a lysine strongly reduced the enzymatic activity (Figure 4C), confirming that the kinase activity is intrinsic to the C-terminal domain. Furthermore, as E. coli does not possess a polynucleotide kinase, a contamination can be excluded.

The 3'-phosphatase activity was analysed as conversion of a non-ligatable DNA nick, which is "blocked" by a $3{ }^{\prime} \mathrm{PO}_{4}$ moiety, to a normal 3'OH-5' $\mathrm{PO}_{4}$ nick that can be subsequently joined by a DNA ligase. Both, D. radiodurans LigA and T4 DNA ligase, were able to ligate the blocked substrate if PNKP was present (data not shown). Even though 3 '-phosphatase activity has been detected, we cannot conclude whether this activity is intrinsic to the PNKP or not. Samples purified from E. coli cells containing only the empty expression vector contained unspecific 3'-phosphatase activity as well and H81A or D82E mutants of DRB0098 did not show any reduced 3'-phosphatase activity, although these two residues represent the conserved HD motif (data not shown). An enzymatic mutant of DRB0098 is required to definitely decide this open question.

\section{Discussion}

DNA ligases are important enzymes acting in DNA replication, recombination and repair. They can be classified by cofactor requirement: those requiring $\mathrm{NAD}^{+}$and those requiring ATP [21]. For many years it was believed that bacteria possess only $\mathrm{NAD}^{+}$-dependent DNA ligases. However, several years ago, it became clear that some bac- 
teria contain an ATP-dependent DNA ligase in addition to their NAD+-dependent DNA ligase [22]. The presence of these ligases suggested that prokaryotes, similar to eukaryotes, could have specific DNA ligases that act in DNA repair and recombination.

In this work, we report the identification of LigA, an $\mathrm{NAD}^{+}$-dependent DNA ligase, and a second putative ATPdependent DNA ligase in the radioresistant bacterium $D$. radiodurans. $\mathrm{NAD}^{+}$-dependent $\mathrm{DNA}$ ligases are highly conserved and it is likely that they are essential for all bacteria [7]. D. radiodurans LigA showed strong ligation activity on a nicked DNA substrate in the presence of $\mathrm{NAD}^{+}$and $\mathrm{MnCl}_{2}$, but only a weak activity in the presence of $\mathrm{MgCl}_{2}$. This $\mathrm{Mn}^{2+}$ preference is not surprising since it was shown that these ions are present in extremely high levels at the D. radiodurans DNA [23] and are essential for $\gamma$-radiation resistance [3]. Moreover, several DNA repair enzymes from $D$. radiodurans, such as UV endonuclease $\beta$ [24] or a family X DNA polymerase with a structure-modulated nuclease activity $[25,26]$, are strongly stimulated by $\mathrm{MnCl}_{2}$. The first step in the ligation process is the formation of an adenylated ligase. According to sequence alignment with other $\mathrm{NAD}^{+}$-dependent DNA ligases, adenylation of the LigA protein is predicted to occur on lysine 128. Indeed, a mutation of this lysine residue to alanine abolished the ligation as well the adenylation activity.

The product of the D. radiodurans gene DRB0100, a diverged homolog of ATP-dependent DNA ligases, contains most of the conserved amino acid residues characteristic of DNA ligases and was shown to be strongly upregulated upon $\gamma$-irradation [8]. We could show that this protein possesses adenylyltransferase activity using $\alpha$ [32P]-ATP as a substrate and that the adenylation occurs specifically at the conserved lysine 40 . This transfer of radioactivity to the wild-type enzyme, but not to the $\mathrm{K} 40 \mathrm{~A}$ mutant, indicates a covalent modification of the respective lysine residue as observed for other ligases. This places DRB0100 in the family of nucleotidyltransferases that includes DNA and RNA ligases as well as RNA capping enzymes. As RNA capping is not characterised for prokaryotes, we focussed our work on the possible ligation activity. However, to our knowledge the presence of RNA capping has not been investigated in $D$. radiodurans and can therefore not completely be excluded. Although different cofactors and various buffer conditions as well as different substrates were used, and the hexa-histidine tag was transferred from the $\mathrm{N}$ - to the $\mathrm{C}$-terminus of the protein, we were not able to show that DRB0100 is active as a DNA or RNA ligase. Nicked DNA substrates, nicked DNA-RNA hybrids prepared by annealing of a $5^{\prime} \mathrm{PO}_{4}$ and a 3' OH RNA strand to a template DNA strand, singlestranded RNA and double-stranded DNA with blunt-ends or overhangs were tested (data not shown). In addition, we analysed total $D$. radiodurans extract with or without previous $\gamma$-irradiation for DNA ligation activity; however no ATP-dependent ligation activity was detectable, even though $\mathrm{NAD}^{+-}$-dependent DNA ligation could be easily detected (data not shown). DRB0100 does not contain any conventional DNA binding motif, suggesting that an additional protein is required for recruitment to nicked DNA.

As DRB0100 is part of a putative repair operon DRB0098DRB0100, we purified the other two proteins to analyse whether the three operon proteins would form a complex capable of DNA ligation. DRB0098 contains a HD-hydrolase family phosphatase domain and a polynucleotide kinase domain and resembles the human repair protein PNKP [27]; DRB0099 is an open reading frame with unknown function and weak similarity to macro domains $[8,10]$. No DNA ligation was detected with any of these three operon proteins or in combinations thereof; thus, we propose the existence of a yet unidentified additional protein involved in the ligation process of DRB0100. Moreover, it cannot be excluded that DRB0100 ligates only special substrates such as specific DNA sequences or RNA intermediates. Interestingly, in several bacteria genes coding for an ATP-dependent DNA ligase have been identified in operons with Ku-homologs. The Ku proteins might recruit the DNA ligase to DNA strand-breaks as is it the case in mammalian cells [28]. In D. radiodurans, however, no Ku-homolog has been identified so far. Another interesting protein that might function in a Ku-like manner is the repair protein PprA from D. radiodurans, which has been shown to tether DNA ends and to stimulate ATPand $\mathrm{NAD}^{+}$-dependent DNA ligases [29,30]. The ATPdependent DNA ligase might function as a backup system to provide additional ligation activity under conditions of high genotoxic stress.

In this work, we furthermore characterised a novel PNKP from $D$. radiodurans, which phosphorylates 5' OH termini. It remains unclear whether it is also able to remove $3^{\prime}$ phosphate groups, thus converting "blocked" DNA nicks to ligatable ones.

PNKPs can be divided into two subgroups according to their domain architecture: the T4-like kinase-phosphatase proteins found in viruses with a function in RNA repair, and the eukaryal-type phosphatase-kinase group involved in DNA repair. The PNKP from D. radiodurans possesses a domain architecture that corresponds to the eukaryal type. So far, only one bacterial PNKP from Chlostridium thermocellum has been described, which in contrast to the D. radiodurans PNKP contains a calcineurin-type phosphatase domain. This enzyme has been shown to possess 5'-polynucleotide kinase, 2'3'-phosphatase and adenylyl- 
transferase activity and has been implicated in RNA repair [17]. It remains to be elucidated if D. radiodurans PNKP is involved in DNA or RNA repair.

The D. radiodurans PNKP possesses an N-terminal phosphatase domain belonging to the HD superfamily. Members of this family are known or predicted phosphohydrolases [18], and a novel subfamily of PNKPs consisting of a 5'-kinase and a 3'-HD phosphohydrolase domain has been proposed based on sequence similarities $[8,9,19]$. These enzymes have a conserved doublet of HD residues that is likely to be required for enzymatic activity. So far, only one PNKP has been shown to possess a 3'phosphatase activity residing in the HD domain, but no mutational analysis is available for this enzyme from the bacteriophage RM378 [19]. However, it was shown, that site-directed mutagenesis of the conserved histidine in a cGMP-phosphodiesterase clearly reduced its catalytic activity [31]. We could show that D. radiodurans PNKP possesses 5'-polynucleotide kinase activity. However, the 3 '-phosphatase activity detected in our assay might result from an unspecific E. coli 3'-phosphatase. H81A or D82E mutants of $D$. radiodurans PNKP did not show a reduced activity in our 3'-phosphatase assays (data not shown). Regarding the polynucleotide kinase activity, the absence of a 5'-polynucleotide kinase in E. coli and the reduced activity of the DRB0098 R371K mutant exclude the possibility of a contamination. In the case of the third protein of the putative repair operon, DRB0099, binding to ADPribose was detected and further work has to be done to elucidate whether ADP-ribosylation might play a role in bacterial DNA repair (Blasius, M., and Hübscher, U., unpublished observation).

\section{Conclusion}

D. radiodurans possesses a classical $\mathrm{NAD}^{+-}$-dependent DNA ligase (LigA) that shows a strong preference for $\mathrm{Mn}$ (II) as a cofactor. A second predicted ATP-dependent DNA ligase (DRB0100) shows adenylyltransferase activity, but no DNA or RNA ligation could be detected in vitro. A predicted 5'-polynucleotide kinase/3'-phosphatase belonging to the same operon was able to convert 5' OH termini to $5^{\prime} \mathrm{PO}_{4}$ termini, thus preparing DNA ends for ligation. In conclusion, D. radiodurans PNKP and LigA are able to heal and ligate DNA nicks. It remains to be assessed whether they play any role in DNA repair or RNA repair in vivo. Also the function of DRB0100 remains to be elucidated and further proteomic and genomic approaches might give more insight into these unsolved questions.

\section{Methods}

\section{Bacterial strains and media}

E. coli DH5 $\alpha$ cells were used for cloning and plasmid preparation (Invitrogen). Recombinant proteins were produced in E. coli BL21(DE3) (Novagen). E. coli cells were grown in LB medium supplemented with $100 \mu \mathrm{g} / \mathrm{ml}$ ampicillin where required.

\section{Enzymes and reagents}

Oligonucleotides synthesis and DNA sequencing were performed by Microsynth. DNA fragments and plasmids were purified with kits from Qiagen. All chemicals used were purchased from Sigma-Aldrich. Immunoblots during protein purifications were done using Tetra-His antibody (Qiagen).

\section{Molecular cloning}

Genomic DNA was isolated from D. radiodurans R1 type strain as described previously [32] and used as a template for PCR amplification of the different genes. PCR reaction mixtures $(50 \mu \mathrm{l})$ contained 1X HF buffer (Finnzymes), $200 \mu \mathrm{M}$ of each dNTP, $400 \mathrm{nM}$ of each forward and reverse primer, 3\% DMSO and 2 units of Phusion ${ }^{\mathrm{TM}}$ HighFidelity DNA Polymerase (Finnzymes). Cycling protocols were designed according to the supplier's recommendations and annealing temperatures were determined using the Tm calculator provided by Finnzymes. PCR products were digested with BamHI and ligated into the pRSETb vector (Invitrogen) using T4 DNA ligase (Fermentas). For site-directed mutageneses the plasmid containing the corresponding wild-type gene was used as a template, the annealing temperature was set to $55^{\circ} \mathrm{C}$, cycle number was reduced to $12-16$, and the PCR product was digested with DpnI to remove the template plasmid. The mutated PCR product was then transformed into DH5 $\alpha$ cells, plasmids were isolated and all constructs were verified by sequencing. PCR primer sequences can be found in Table 1 .

\section{Expression and purification of recombinant proteins}

Cultures of E. coli BL21(DE3) cells transformed with the respective expression plasmid were grown in $\mathrm{LB}$ medium supplemented with ampicillin at $37^{\circ} \mathrm{C}$ to an $\mathrm{OD}_{600 \mathrm{~nm}}$ of $0.4-0.8$, then IPTG was added to $1 \mathrm{mM}$ final concentration and cells were further incubated for $2-4 \mathrm{~h}$ at $37^{\circ} \mathrm{C}$. Cells were pelleted by centrifugation $\left(4^{\circ} \mathrm{C}, 4,700 \mathrm{~g}, 30\right.$ minutes) in a Sorvall H6000A rotor. All protein purification steps were performed at $4{ }^{\circ} \mathrm{C}$ or on ice. Cell pellets were resuspended in $30 \mathrm{ml}$ of buffer $\mathrm{N}(500 \mathrm{mM} \mathrm{NaCl}, 30$ $\mathrm{mM}$ phosphate buffer, $\mathrm{pH}$ 7.5, $10 \mathrm{mM}$ Tris- $\mathrm{HCl}, \mathrm{pH} 7.5$, $10 \mathrm{mM}$ imidazole, and $1 \mathrm{mM}$ PMSF) and lysed with a French press. To ensure complete lysis, cells were in addition sonicated ( 2 minutes, $40 \%$ duty cycle, Branson Sonifier ${ }^{\circledR}$ Cell disruptor B15). The lysate was centrifuged $\left(4^{\circ} \mathrm{C}\right.$, $43,000 \mathrm{~g}$, 30 minutes) in a Sorvall SS-34 rotor and the supernatant was loaded onto a $1 \mathrm{ml}$ HisTrap $\mathrm{HP}^{\mathrm{TM}}$ column (GE Healthcare) using an ÄKTApurifier ${ }^{\mathrm{TM}}$ (GE Healthcare). The column was washed with buffer $\mathrm{N}$ containing $50 \mathrm{mM}$ $\mathrm{NaCl}$ and $50 \mathrm{mM}$ imidazole and protein was eluted with $50 \mathrm{mM} \mathrm{NaCl}$ and $300 \mathrm{mM}$ imidazole. Protein was pooled according to a Coomassie Blue R250 stained SDS-PAGE 
and loaded onto the next column equilibrated in buffer $\mathrm{A}$ (40 mM Tris-HCl, pH 7.5, $50 \mathrm{mM} \mathrm{NaCl}, 15 \%$ (v/v) glycerol, $1 \mathrm{mM}$ EDTA, and $1 \mathrm{mM}$ 2-mercaptoethanol). For LigA wt and K128A mutant the protein was loaded onto a $1 \mathrm{ml}$ Heparin $\mathrm{HP}^{\mathrm{TM}}$ column and eluted with a gradient from 50 to $1000 \mathrm{mM} \mathrm{NaCl}$ in buffer A. LigA eluted at 350 $\mathrm{mM} \mathrm{NaCl}$. Protein was pooled, diluted to $50 \mathrm{mM} \mathrm{NaCl}$ with buffer A without $\mathrm{NaCl}$ and loaded onto a HiTrap Q $\mathrm{HP}^{\mathrm{TM}}$ column. Elution was done with a gradient from 50$1000 \mathrm{mM} \mathrm{NaCl}$. Protein eluted at $400 \mathrm{mM} \mathrm{NaCl}$. Fractions that contained nearly homogenous LigA protein as judged by SDS-PAGE were pooled, dialysed to buffer S (20 mM Tris-HCl, pH 7.5, 25\% (v/v) glycerol, $50 \mathrm{mM} \mathrm{NaCl}, 1$ $\mathrm{mM}$ 2-mercaptoethanol, and $0.5 \mathrm{mM}$ EDTA), and stored at $-80^{\circ} \mathrm{C}$.

For DRB0100 wt and K40A mutant the pool obtained from the HisTrap $\mathrm{HP}^{\mathrm{TM}}$ column was loaded onto a $1 \mathrm{ml}$ HiTrap SP HP ${ }^{\mathrm{Tm}}$ column equilibrated with buffer A. DRB0100 was retrieved in the flow-through, which was diluted to $25 \mathrm{mM} \mathrm{NaCl}$ and loaded onto a HiTrap Q HP ${ }^{\mathrm{rm}}$ column. Elution was done using a gradient from 25-1000 $\mathrm{mM} \mathrm{NaCl}$ and DRB0100 protein eluted at $50 \mathrm{mM} \mathrm{NaCl}$. The protein pool was dialysed to buffer $S$ and stored at $80^{\circ} \mathrm{C}$.

The HisTrap $\mathrm{HP}^{\mathrm{TM}}$ pools of DRB0098 wt and R371K mutant were loaded onto a $1 \mathrm{ml}$ Heparin column and eluted as described for LigA. Protein was pooled, diluted to $25 \mathrm{mM} \mathrm{NaCl}$ and loaded onto a $1 \mathrm{ml} \mathrm{SP} \mathrm{HP}{ }^{\text {тм }}$ column. Protein was eluted at $50 \mathrm{mM} \mathrm{NaCl}$, tested for purity as described above, pooled and dialysed to buffer $\mathrm{S}$ for storage at $-80^{\circ} \mathrm{C}$. Protein concentrations were determined using bovine serum albumin standards and a BioRad protein assay.

\section{Adenylyltransferase activity assays}

For DRB0100, reaction mixture $(20 \mu \mathrm{l})$ containing $50 \mathrm{mM}$ Tris-HCl, pH 7.5, $5 \mathrm{mM}$ dithiothreitol, $5 \mathrm{mM} \mathrm{MgCl}_{2}, 1.25$ $\mu \mathrm{M} \alpha-\left[{ }^{32} \mathrm{P}\right]-\mathrm{ATP}$ and the indicated amounts of protein were incubated for 15 minutes at $30^{\circ} \mathrm{C} .20 \mu \mathrm{l}$ of $2 \mathrm{X} \mathrm{Lae}$ mmli buffer were added, samples were heated for $5 \mathrm{~min}$ - utes at $95^{\circ} \mathrm{C}$ and products were separated on a $12 \%$ standard SDS-PAGE. The intermediates were detected by autoradiography and the gel was stained by Coomassie Blue R250 to visualize the molecular weight markers. For LigA, the reaction mixture $(10 \mu \mathrm{l})$ contained $50 \mathrm{mM}$ Tris$\mathrm{HCl}, \mathrm{pH} 6.8,5 \mathrm{mM}$ dithiothreitol, $1 \mathrm{mM} \mathrm{MnCl}_{2}, 1 \mu \mathrm{g}$ of protein and $0.1 \mu \mathrm{M}\left[{ }^{32} \mathrm{P}\right]-\mathrm{NAD}^{+}$. The reaction was incubated for 15 minutes at $30^{\circ} \mathrm{C}$, stopped with $10 \mu \mathrm{l}$ of $2 \mathrm{X}$ Laemmli buffer, heated for 5 minutes at $95^{\circ} \mathrm{C}$ and loaded onto a $10 \%$ SDS-PAGE. Prestained markers were loaded to compare protein sizes. Free [32P]-NAD ${ }^{+}$and ligase-AMP complexes were visualized by autoradiography.

\section{Preparation of DNA substrates}

The DNA substrate used to measure the ligation activity on a double-stranded substrate carrying a single-strand nick was prepared as described [33], the 19 nucleotide DNA strand was phosphorylated using $\gamma$-[32P]-ATP and T4 polynucleotide kinase (New England Biolabs). Free $\gamma$ [32P]-ATP was removed on a MicroSpin ${ }^{\mathrm{TM}} \mathrm{G}-25$ column (GE Healthcare). The sequences are presented in Table 3.

\section{Ligation assays}

The 5'-[ $\left.{ }^{32} \mathrm{P}\right]$-labelled DNA substrate was incubated for 30 minutes with the indicated amounts of recombinant protein at $30^{\circ} \mathrm{C}$. Reactions were performed in a final volume of $10 \mu \mathrm{l}$ containing $50 \mathrm{fmol}$ of $5^{\prime}-\left[{ }^{32} \mathrm{P}\right]$-labelled DNA, 50 $\mathrm{mM}$ Tris- $\mathrm{HCl}, \mathrm{pH}$ 6.8, $1 \mathrm{mM} \mathrm{MnCl}_{2}, 5 \mathrm{mM}$ dithiothreitol and $1 \mathrm{mM}$ ATP or $5 \mu \mathrm{M} \mathrm{NAD}{ }^{+}$unless otherwise mentioned. The reactions were stopped by adding $10 \mu \mathrm{l}$ of loading buffer (95\% formamide, $20 \mathrm{mM}$ EDTA, 0.05\% bromphenol blue, $0.05 \%$ xylene cyanol), heated for 5 minutes at $95^{\circ} \mathrm{C}$ and products were separated on a $15 \%$ denaturing polyacrylamide gel containing $8 \mathrm{M}$ urea and $15 \%$ formamide. After autoradiography, the signals were quantified on a PhosphorImager using the ImageQuant software (Molecular Dynamics). Ligation was quantified by calculating the product/(product+substrate) ratio thus allowing a correction for loading errors. To determine the $K_{\text {Mnicked DNA }}$ value of the D. radiodurans $\mathrm{NAD}^{+}$-dependent DNA ligase, the reactions contained $50 \mathrm{mM}$ Tris- $\mathrm{HCl}, \mathrm{pH}$ 6.8, $5 \mathrm{mM}$ dithiothreitol, $1 \mathrm{mM} \mathrm{MnCl}_{2}, 5 \mu \mathrm{M} \mathrm{NAD}^{+}, 10-$

Table 3: Oligonucleotide sequences used to prepare DNA substrates for the enzyme assays performed in this study

\begin{tabular}{lll}
\hline Oligonucleotide & Length $(\mathbf{n t})$ & Sequence (5'-3') \\
\hline RNA-5' nick & 19 & CAGCAGCAAAUGAAAAAUC \\
DNA-5' nick & 19 & CAGCAGCAAATGAAAAATC \\
RNA-3' nick & 25 & CCUGCAACAGUGCCACGCUGAGAGC \\
DNA-3' nick & 25 & CCTGCAACAGTGCCACGCTGAGAGC \\
DNA-3'P nick & 25 & CCTGCAACAGTGCCACGCTGAGAGC-P \\
DNA-opposite & 46 & AGATTTTCATTTGCTGCTGGCTCTCAG \\
& & CGTGGCACTGTTGCAGGC \\
Kinase-DNA & 25 & GCTTTCCGATACCGGGGTCTTCCG \\
\hline
\end{tabular}

All oligonucleotides were PAGE purified and labelled as described in the Methods section. P stands for a 3' phosphate group. 
$150 \mathrm{fmol}$ of [32P]-labelled nicked DNA substrate and $2 \mathrm{ng}$ of enzyme. The reactions were incubated for 15 minutes at $30^{\circ} \mathrm{C}$. The ligated products were quantified by Phos-

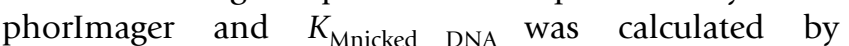
Lineweaver-Burk plotting as a mean of 3 independent experiments.

\section{Polynucleotide kinase assays}

The indicated amounts of recombinant protein were incubated with 1 pmol of DNA substrate (kinase-DNA in Table 3 ) in a volume of $10 \mu \mathrm{l}$ containing $50 \mathrm{mM}$ Tris- $\mathrm{HCl}$, $\mathrm{pH} 7.5,0.25 \mathrm{mM} \mathrm{MnCl}_{2}, 5 \mathrm{mM}$ dithiothreitol and 0.25 $\mu \mathrm{Ci}$ of $\gamma-\left[{ }^{32} \mathrm{P}\right]-\mathrm{ATP}$ (GE Healthcare) for 30 minutes at $30^{\circ} \mathrm{C}$. Reactions were stopped with $10 \mu \mathrm{l}$ of loading buffer, heated for 5 minutes at $95^{\circ} \mathrm{C}$ and separated on a $15 \%$ denaturing polyacrylamide gel containing $8 \mathrm{M}$ urea and $15 \%$ formamide. Signals of ${ }^{32} \mathrm{P}-\mathrm{DNA}$ were visualized by autoradiography.

\section{Authors' contributions}

$\mathrm{MB}$ performed most of the experiments, did most of the cloning and protein purifications, analysed the data and wrote the manuscript. RB helped characterising the NAD ${ }^{+}-$ dependent DNA ligase. IS performed part of the cloning and protein purification. $\mathrm{MB}$, IS and UH conceived of the study. UH helped analysing the data and preparing the manuscript. All authors read and approved the final version of the manuscript.

\section{Additional material}

\section{Additional file 1}

Factors tested to detect DNA ligation activity of the DRB0100 gene product. This table lists the various buffer conditions and proteins tested in DNA ligation assays for the DRB0100 gene product.

Click here for file

[http://www.biomedcentral.com/content/supplementary/14712199-8-69-S1.pdf]

\section{Additional file 2}

Ligation substrates tested to detect DNA ligation activity of the DRB0100 gene product. This table shows the sequences of the different oligonucleotides that were used to prepare ligation substrates for the DRB0100 gene product.

Click here for file

[http://www.biomedcentral.com/content/supplementary/14712199-8-69-S2.pdf]

\section{Acknowledgements}

We thank M. Toueille, K. Makarova and E. Gaidamakova for helpful suggestions and discussions. We also thank R. Mak and U. Wimmer for critical reading of the manuscript. MB, RB and $U H$ are supported by the Swiss National Science Foundation (Grant 3 I00A0-1093 I2) and RB, IS and UH by the University of Zurich.

\section{References}

I. Cox MM, Battista JR: Deinococcus radiodurans - the consummate survivor. Nat Rev Microbiol 2005, 3(I I):882-892.

2. Daly MJ, Gaidamakova EK, Matrosova VY, Vasilenko A, Zhai M, Leapman RD, Lai B, Ravel B, Li SM, Kemner KM, Fredrickson JK: Protein oxidation implicated as the primary determinant of bacterial radioresistance. PLoS Biol 2007, 5(4):e92.

3. Daly MJ, Gaidamakova EK, Matrosova VY, Vasilenko A, Zhai M, Venkateswaran A, Hess M, Omelchenko MV, Kostandarithes HM, Makarova KS, Wackett LP, Fredrickson JK, Ghosal D: Accumulation of Mn(II) in Deinococcus radiodurans facilitates gammaradiation resistance. Science 2004, 306(5698): $1025-1028$.

4. Bowater R, Doherty AJ: Making ends meet: repairing breaks in bacterial DNA by non-homologous end-joining. PLoS Genet 2006, 2(2):e8.

5. Weller GR, Kysela B, Roy R, Tonkin LM, Scanlan E, Della M, Devine SK, Day JP, Wilkinson A, d'Adda di Fagagna F, Devine KM, Bowater RP, Jeggo PA, Jackson SP, Doherty AJ: Identification of a DNA nonhomologous end-joining complex in bacteria. Science 2002, 297(5587): 1686-1689.

6. Zahradka K, Slade D, Bailone A, Sommer S, Averbeck D, Petranovic $M$, Lindner $A B$, Radman M: Reassembly of shattered chromosomes in Deinococcus radiodurans. Nature 2006, 443(7 I I I):569-573.

7. Wilkinson A, Day J, Bowater R: Bacterial DNA ligases. Mol Microbiol 200I, 40(6): I24I-I248.

8. Liu Y, Zhou J, Omelchenko MV, Beliaev AS, Venkateswaran A, Stair J Wu L, Thompson DK, Xu D, Rogozin IB, Gaidamakova EK, Zhai M, Makarova KS, Koonin EV, Daly MJ: Transcriptome dynamics of Deinococcus radiodurans recovering from ionizing radiation. Proc Natl Acad Sci USA 2003, I00(7):4191-4196.

9. Makarova KS, Aravind L, Wolf YI, Tatusov RL, Minton KW, Koonin EV, Daly MJ: Genome of the extremely radiation-resistant bacterium Deinococcus radiodurans viewed from the perspective of comparative genomics. Microbiol Mol Biol Rev 200I, 65(I):44-79.

10. Omelchenko MV, Wolf YI, Gaidamakova EK, Matrosova VY, Vasilenko A, Zhai M, Daly MJ, Koonin EV, Makarova KS: Comparative genomics of Thermus thermophilus and Deinococcus radiodurans: divergent routes of adaptation to thermophily and radiation resistance. $B M C$ Evol Biol 2005, 5:57.

1I. Henner WD, Grunberg SM, Haseltine WA: Sites and structure of gamma radiation-induced DNA strand breaks. J Biol Chem 1982, 257(19): I I750-II754.

12. Henner WD, Rodriguez LO, Hecht SM, Haseltine WA: gamma Ray induced deoxyribonucleic acid strand breaks. 3' Glycolate termini. J Biol Chem 1983, 258(2):7। I-7I3.

13. Amitsur M, Levitz R, Kaufmann G: Bacteriophage T4 anticodon nuclease, polynucleotide kinase and RNA ligase reprocess the host lysine tRNA. Embo J 1987, 6(8):2499-2503.

14. Audebert M, Salles B, Weinfeld M, Calsou P: Involvement of polynucleotide kinase in a poly(ADP-ribose) polymerase-I. dependent DNA double-strand breaks rejoining pathway. J Mol Biol 2006, 356(2):257-265.

15. Chappell C, Hanakahi LA, Karimi-Busheri F, Weinfeld M, West SC: Involvement of human polynucleotide kinase in doublestrand break repair by non-homologous end joining. Embo J 2002, 2 I ( I I):2827-2832.

16. Whitehouse CJ, Taylor RM, Thistlethwaite A, Zhang H, KarimiBusheri F, Lasko DD, Weinfeld M, Caldecott KW: XRCCI stimulates human polynucleotide kinase activity at damaged DNA termini and accelerates DNA single-strand break repair. Cell 200I, 104(I):107-II7.

17. Martins A, Shuman S: An end-healing enzyme from Clostridium thermocellum with $5^{\prime}$ 'kinase, 2',3' phosphatase, and adenylyltransferase activities. Rna 2005, I I (8): | 27|- I 280.

18. Aravind L, Koonin EV: The HD domain defines a new superfamily of metal-dependent phosphohydrolases. Trends Biochem Sci 1998, 23( ( 2):469-472.

19. Blondal T, Hjorleifsdottir S, Aevarsson A, Fridjonsson $\mathrm{OH}$, Skirnisdottir S, Wheat JO, Hermannsdottir AG, Hreggvidsson GO, Smith $\mathrm{AV}, \mathrm{Kristjansson} \mathrm{JK}$ : Characterization of a 5'-polynucleotide kinase/3'-phosphatase from bacteriophage RM378. J Biol Chem 2005, 280(7):5 I88-5I94. 
20. Wang LK, Shuman S: Mutational analysis defines the $\mathbf{5}^{\prime}$-kinase and 3'-phosphatase active sites of T4 polynucleotide kinase. Nucleic Acids Res 2002, 30(4): $1073-1080$.

21. Doherty AJ, Suh SW: Structural and mechanistic conservation in DNA ligases. Nucleic Acids Res 2000, 28(2 I):405I-4058.

22. Weller GR, Doherty AJ: A family of DNA repair ligases in bacteria? FEBS Lett 200I, 505(2):340-342.

23. Leibowitz PJ, Schwartzberg LS, Bruce AK: The in vivo association of manganese with the chromosome of Micrococcus radiodurans. Photochem Photobiol 1976, 23(I):45-50.

24. Evans DM, Moseley BE: Identification and initial characterisation of a pyrimidine dimer UV endonuclease (UV endonuclease beta) from Deinococcus radiodurans; a DNA-repair enzyme that requires manganese ions. Mutat Res 1985, | 45(3): | | 9-128.

25. Lecointe F, Shevelev IV, Bailone A, Sommer S, Hubscher U: Involvement of an $X$ family DNA polymerase in double-stranded break repair in the radioresistant organism Deinococcus radiodurans. Mol Microbiol 2004, 53(6): 172 I- 1730.

26. Blasius M, Shevelev I, Jolivet E, Sommer S, Hubscher U: DNA polymerase $X$ from Deinococcus radiodurans possesses a structure-modulated 3 '--> $>5$ ' exonuclease activity involved in radioresistance. Mol Microbiol 2006, 60(I):165-176.

27. Jilani A, Ramotar D, Slack C, Ong C, Yang XM, Scherer SW, Lasko DD: Molecular cloning of the human gene, PNKP, encoding a polynucleotide kinase 3'-phosphatase and evidence for its role in repair of DNA strand breaks caused by oxidative damage. J Biol Chem 1999, 274(34):24I76-24I86.

28. Nick McElhinny SA, Snowden CM, McCarville J, Ramsden DA: Ku recruits the XRCC4-ligase IV complex to DNA ends. Mol Cell Biol 2000, 20(9):2996-3003

29. Narumi I, Satoh K, Cui S, Funayama T, Kitayama S, Watanabe H: PprA: a novel protein from Deinococcus radiodurans that stimulates DNA ligation. Mol Microbiol 2004, 54(I):278-285.

30. Murakami M, Narumi I, Satoh K, Furukawa A, Hayata I: Analysis of interaction between DNA and Deinococcus radiodurans PprA protein by Atomic force microscopy. Biochim Biophys Acto 2006, I 764(I):20-23.

31. Turko IV, Francis SH, Corbin JD: Potential roles of conserved amino acids in the catalytic domain of the cGMP-binding cGMP-specific phosphodiesterase. J Biol Chem 1998, 273( I I):6460-6466.

32. Eggington JM, Haruta N, Wood EA, Cox MM: The single-stranded DNA-binding protein of Deinococcus radiodurans. $B M C$ Microbiol 2004, 4:2.

33. Smirnova E, Toueille M, Markkanen E, Hubscher U: The human checkpoint sensor and alternative DNA clamp Rad9-Rad IHus I modulates the activity of DNA ligase I, a component of the long-patch base excision repair machinery. Biochem J 2005, 389(Pt I): 13-17.

34. Shuman S, Schwer B: RNA capping enzyme and DNA ligase: a superfamily of covalent nucleotidyl transferases. Mol Microbiol 1995, I 7(3):405-410.

35. Thompson JD, Higgins DG, Gibson TJ: CLUSTAL W: improving the sensitivity of progressive multiple sequence alignment through sequence weighting, position-specific gap penalties and weight matrix choice. Nucleic Acids Res 1994, 22(22):4673-4680.

36. Marchler-Bauer A, Bryant SH: CD-Search: protein domain annotations on the fly. Nucleic Acids Res 2004:W327-33I.
Publish with Bio Med Central and every scientist can read your work free of charge

"BioMed Central will be the most significant development for disseminating the results of biomedical research in our lifetime. "

Sir Paul Nurse, Cancer Research UK

Your research papers will be:

- available free of charge to the entire biomedical community

- peer reviewed and published immediately upon acceptance

- cited in PubMed and archived on PubMed Central

- yours - you keep the copyright
BioMedcentral 